\title{
PREPARATION OF MANGANESE DIOXIDE MODIFIED GLASSY CARBON ELECTRODE BY A NOVEL FILM PLATING/CYCLIC VOLTAMMETRY METHOD FOR $\mathrm{H}_{2} \mathrm{O}_{2}$ DETECTION
}

\author{
LE WEN-ZHI LIU YOU-QIN* HU GUANG-QI
}

\author{
Department of Applied Chemistry, College of Sciences, South China Agriculture University, Guangzhou, Guangdong 510642, PR China
}

(Received: December 16, 2009 - Accepted: August 31, 2009)

\begin{abstract}
Manganese dioxide modified glassy carbon electrode $\left(\mathrm{MnO}_{2} / \mathrm{GC}\right)$ was prepared by a novel film plating/cyclic voltammetry method for the determination of $\mathrm{H}_{2} \mathrm{O}_{2}$. A manganese film was first cathodically deposited on the surface of glassy carbon electrode from $\mathrm{MnCl}_{2}$ solution at the potential of $-1.4 \mathrm{~V}$ versus $\mathrm{Ag} /$ $\mathrm{AgCl}$ (satd. $\mathrm{KCl}$ ), and then a well defined manganese dioxide was deposited on the surface of glassy carbon electrode by cyclic voltammetry at potential range $-0.6 \sim 0.6 \mathrm{~V}$, scan rate $100 \mathrm{mV} \mathrm{s}^{-1}$ in $0.1 \mathrm{~mol} \mathrm{~L}^{-1} \mathrm{NaOH}$ solution. The resulted modified electrode was characterized by cyclic voltammetry and scanning electron microscopy (SEM), which showed excellent electrocatalytic activity for the oxidation of $\mathrm{H}_{2} \mathrm{O}_{2}$. The chronoamperometric detection of $\mathrm{H}_{2} \mathrm{O}_{2}$ was carried out at 0.6 $\mathrm{V}$ in phosphate buffer solution $\mathrm{pH} 7.38$ containing $0.1 \mathrm{~mol} \mathrm{~L}^{-1} \mathrm{KCl}$ and the linear relationship of response current on $\mathrm{H}_{2} \mathrm{O}_{2}$ concentration was obtained in the range from $4.1 \times 10^{-10}$ to $1 \times 10^{-4} \mathrm{~mol} \mathrm{~L}^{-1}$ with a minimum detectable concentration of $3 \times 10^{-10} \mathrm{~mol} \mathrm{~L}^{-1}[\mathrm{~S} / \mathrm{N}$ (signal noise ratio) $=3]$. The response time of the electrode to achieve $95 \%$ of the steady-state current was $<2 \mathrm{~s}$. No measurable reduction in analytical performance of the modified electrode was found by storing the electrode in ambient conditions for 30 days. This modified electrode has many advantages such as simple preparation procedure, remarkable catalytic activity, good reproducibility and long term stability of signal response during hydrogen peroxide oxidation. The deposition of manganese dioxide on the surface of GC appears to be a highly efficient method for the development of a new class of sensitive, stable and reproducible hydrogen peroxide electrochemical sensor.
\end{abstract}

Keywords: Manganese dioxide, Film plating/Cyclic voltammetry, Glassy carbon electrode, Electrocatalysis.

\section{INTRODUCTION}

Hydrogen peroxide $\left(\mathrm{H}_{2} \mathrm{O}_{2}\right)$ is a very important intermediate in environmental and biological reactions. The monitoring of $\mathrm{H}_{2} \mathrm{O}_{2}$ with a reliable, rapid and economic method is of great significance for numerous processes. Several analytical techniques such as titrimetry, spectrophotometry and chemiluminesence have been employed for its determination ${ }^{1}$. Electrochemical methods have been proved to be an effective and inexpensive way for $\mathrm{H}_{2} \mathrm{O}_{2}$ determination. The direct oxidation of $\mathrm{H}_{2} \mathrm{O}_{2}$ at bare usual electrodes is not suited for analytical application due to the slow electrode kinetics and high over-potential material, so preparation of chemical modified electrode (CME) with catalytic function is of practical significance. The methods reported for preparing CME contained sol-gel technique ${ }^{2}$, electrodeposition ${ }^{3}$, pyrolysis oxidation $^{4}$, self-assembly ${ }^{5}$, and so on.

Since inorganic surface mediators have the major advantages of efficient electrocatalysis and inherent stability, as needed for practical analytical work ${ }^{6}$, some workers have been devoted to the preparation and characterization of inorganic catalytic centers ${ }^{7-9}$. The reported inorganic materials included clay, zeolite, metal phthalocyanine, metalloporphyrin, transition metal particles, transitional metal oxides, oxometalates and polynuclear transition metal hexacyanometallate ${ }^{10}$. The potential applications of transition metal coating in the field of science and technology have been widely concerned by people. So far, different metal oxide particles, such as manganese oxide ${ }^{11}$, iron oxide ${ }^{12}$ tungsten oxide ${ }^{13}$, lead oxide ${ }^{14}$, ruthenium oxide ${ }^{15}$ and cobalt oxide ${ }^{16}$, have been successfully used for immobilization of enzymes and proteins and in fabrication of $\mathrm{H}_{2} \mathrm{O}_{2}$ sensor. Manganese dioxide and manganese oxide-materials have been widely used for amperometric determination of bonded glucose $\mathrm{e}^{17}$, fuel cells ${ }^{18}$, rechargeable alkaline batteries ${ }^{19}$.

For the past decades, manganese dioxide has been proven to be a suitable mediator for catalytic substance to reduce the over potential for $\mathrm{H}_{2} \mathrm{O}_{2}$ oxidation. Taba and Wang ${ }^{20}$ prepared a film of $\mathrm{MnO}_{2}$ deposited on glassy carbon electrode (GCE) from $\mathrm{MnCl}_{2} / \mathrm{NaOH}$ solution, which showed that it could be used in alkaline solution and exhibited highly stable and effective electrocatalytic oxidation of hydrogen peroxide and hydrazine compounds. Bai et al. ${ }^{21}$ fabricated a $\mathrm{MnO}_{2}$ nanoparticles modified electrode with bi-catalytic activity to $\mathrm{H}_{2} \mathrm{O}_{2}$. Since the electrocatalytic property of CME is obviously affected by physical and chemical state of the modifiers on electrode surface, designing proper film preparation method is essential. For this purpose, several methods, such as bulk-modified ${ }^{17}$, reduce potassium permanganate ${ }^{22}$, cyclic voltammetry ${ }^{23}$, have been used. But these preparation methods suffered from complex preparation process, time-consuming and uneven film that was not in close contact with electrodes, easily shed and prone to crack.

In this paper, a new film plating/cyclic voltammetry method has been developed to electrodeposit manganese dioxide film on the surface of GCE, whose most virtue consists in preventing metal ions from forming sedimentation with other components in electrolyte. Compared with above methods, the course of film plating/cyclic voltammetry method is easier to control the number of active sites on electrode surface and the film is uniform and in close contact with electrode. The factors, which affected the process of modification, electrochemical property of film, were evaluated by electrochemical techniques. Determination of $\mathrm{H}_{2} \mathrm{O}_{2}$ and interference of some substances probably coexisted with $\mathrm{H}_{2} \mathrm{O}_{2}$ were also investigated and the possible interacting mechanism of sensor was discussed. The sensor has been used to detect $\mathrm{H}_{2} \mathrm{O}_{2}$ in real water samples and exhibits some advantages, such as simple preparation procedures, high activity, good stability and reproducibility.

\section{EXPERIMENTAL}

\section{Reagents}

Analytical grade $\mathrm{MnCl}_{2} \cdot 4 \mathrm{H}_{2} \mathrm{O}, \mathrm{KCl}, \mathrm{Na}_{2} \mathrm{HPO}_{4}, \mathrm{KH}_{2} \mathrm{PO}_{4}, \mathrm{H}_{2} \mathrm{O}_{2}(30 \%)$ and so on were all purchased from Shanghai Chemical Reagent Company (Shanghai, China) and used without further purification. Stock solutions were prepared with doubly-distilled deionized water. $0.5 \mathrm{~mol} \mathrm{~L}^{-1} \mathrm{H}_{2} \mathrm{O}_{2}$ was standardized by $\mathrm{KMnO}_{4}$. The phosphate buffer solution (PBS) with desired $\mathrm{pH}$ was prepared by mixing different volume of $\mathrm{Na}_{2} \mathrm{HPO}_{4}\left(1 / 15 \mathrm{~mol} \mathrm{~L}^{-1}\right)$ and $\mathrm{KH}_{2} \mathrm{PO}_{4}(1 / 15 \mathrm{~mol}$ $\mathrm{L}^{-1}$ ) solutions.

\section{Instrumentation}

Cyclic voltammetry (CV) and Chronoamperometry were carried out on a $\mathrm{CHI} 660 \mathrm{C}$ electrochemical analyzer (Shanghai Chenhua Co, China). A threeelectrode configuration consisted of a modified glassy carbon electrode (GC $\Phi 3.7 \mathrm{~mm})$ as a working electrode, a reference electrode $(\mathrm{Ag} / \mathrm{AgCl}$ satd. $\mathrm{KCl})$ and a counter electrode (Pt wire, length $5 \mathrm{~mm}$, diameter $1 \mathrm{~mm}$ ). Environmental Scanning Electron Microscopy image (ESEM) was obtained using a XL-30 microscope (Philips Co. Netherlands).

\section{$\mathrm{MnO}_{2} / \mathrm{GC}$ electrode preparation}

Before modification, the GC surface was carefully polished with aluminum $(\Phi 0.05 \mu \mathrm{m})$ slurry on polishing cloth and then sonicated successively in ethanol, $\mathrm{HNO}_{3}+\mathrm{H}_{2} \mathrm{O}(1: 1, \mathrm{~V} / \mathrm{V})$ and doubly distilled water for $2 \mathrm{~min}$, respectively. Last, the water on electrode was dried with high purity $\mathrm{N}_{2}(99.999 \%)$.

A manganese film was first electrodeposited on GC surface by maintaining potential $-1.4 \mathrm{~V}$ for $180 \mathrm{~s}$ in $1.8 \mu \mathrm{mol} \mathrm{L}^{-1} \mathrm{MnCl}_{2}$ solution containing $0.6 \mathrm{~mol}$ $\mathrm{L}^{-1} \mathrm{KCl}$. Then, the electrode was rinsed with water and dried with $\mathrm{N}_{2}$. After that, the manganese film on $\mathrm{GC}$ was put in $0.1 \mathrm{~mol} \mathrm{~L}^{-1} \mathrm{NaOH}$ solution and scanned repetitively for 20 cycles under potential range $-0.6 \sim 0.6 \mathrm{~V}$ at 0.05 $\mathrm{V} \mathrm{s}^{-1}$. By this means, a well defined and adhesive $\mathrm{MnO}_{2}$ film was bound to $\mathrm{GC}$ surface.

During all experiments, the electrolyte was pre-purged with high purity $\mathrm{N}_{2}$ for 10 min to remove $\mathrm{O}_{2}$ and a continuous flow of $\mathrm{N}_{2}$ gas was maintained over 
the solution. Experiments were performed at room temperature $\left(25 \pm 1^{\circ} \mathrm{C}\right)$.

Electrochemical measurements

Cyclic voltammetry (CV) and Chronoamperometry were carried out in an electrochemical cell holding $12 \mathrm{ml}$ of $1 / 15 \mathrm{~mol} \mathrm{~L}^{-1}$ phosphate buffer $(\mathrm{pH}=7.38)$ and $0.1 \mathrm{~mol} \mathrm{~L}^{-1} \mathrm{KCl}$. In chronoamperometry, a holding potential of $0.6 \mathrm{~V}$ was applied to the modified electrode and the background current was allowed to decay to a constant value before $\mathrm{H}_{2} \mathrm{O}_{2}$ solution was added to the cell. The current-time curve for the amperometric experiment was recorded and calibration curve was obtained by amperometric responses when the same amount of $\mathrm{H}_{2} \mathrm{O}_{2}$ standard solution was added into the electrochemical cell.

\section{RESULTS AND DISCUSSION}

\section{Preparation of $\mathrm{MnO}_{2} / \mathrm{GC}$ electrode}

Electrochemical behavior of $\mathrm{Mn}^{2+}$ on GC

Fig. 1 shows the typical cyclic voltammogram of GC electrode in $0.6 \mathrm{~mol}$ $\mathrm{L}^{-1} \mathrm{KCl}$ electrolyte containing $1.8 \mu \mathrm{mol} \mathrm{L}^{-1} \mathrm{MnCl}_{2}$. There are four redox peaks in curve a which is the first cyclic voltammogram at scan rate of $0.02 \mathrm{~V} \mathrm{~s}^{-1}$. Peak $\mathrm{A}_{0}$ is very broad, which can be attributed to the oxidation of $\mathrm{Mn}\left(\mathrm{Mn} \rightarrow \mathrm{Mn}^{2+}\right)$ produced at potential lower than $-1.2 \mathrm{~V}^{24}$. The anodic peak in $\mathrm{A}_{3}$ region and cathodic peak in $\mathrm{C}_{1}$ region are found to split into two spaced peaks in the voltammogram. The anodic peak $\mathrm{A}_{3}$ may be attributed to two distinct oxidation mechanisms represented by Eqs. (1)-(6)

ECE mechanism

$$
\begin{aligned}
& \mathrm{Mn}^{2+} \rightarrow \mathrm{Mn}^{3+}+\mathrm{e}^{-} \\
& \mathrm{Mn}^{3+}+2 \mathrm{H}_{2} \mathrm{O} \rightarrow \mathrm{MnOOH}+3 \mathrm{H}^{+} \\
& \mathrm{MnOOH} \rightarrow \mathrm{MnO} \mathrm{H}^{+}+\mathrm{e}^{-} \\
& \text {Disproportionation mechanism } \\
& \mathrm{Mn}^{2+} \rightarrow \mathrm{Mn}^{3+}+\mathrm{e}^{-} \\
& 2 \mathrm{Mn}^{3+} \rightarrow \mathrm{Mn}^{2+}+\mathrm{Mn}^{4+} \\
& \mathrm{Mn}^{4+}+2 \mathrm{H}_{2} \mathrm{O} \rightarrow \mathrm{MnO}_{2}+4 \mathrm{H}^{+}
\end{aligned}
$$

The cathodic peak in the $\mathrm{C}_{1}$ region may be due to the reduction of $\mathrm{MnO}_{2}$ to $\mathrm{MnOOH}$, which is further reduced to $\mathrm{Mn}$ (II) in the $\mathrm{C}_{2}$ potential region ${ }^{26}$. Curve b illustrates the second cyclic voltammogram of GC electrode in the same solution. There are additional anodic peak $\mathrm{A}_{1}$ at around $0.25 \mathrm{~V}$ and much broader anodic oxide wave $A_{2}$, which didn't appear in the first cyclic voltammogram, indicating that their appearance resulted from the formation of $\mathrm{MnO}_{2}\left(\right.$ peak $\left.\mathrm{A}_{3}\right) . \mathrm{A}_{1}, \mathrm{~A}_{2}$ can be attributed to the oxidation reaction of $\mathrm{Mn}(\mathrm{III}) /$ $\mathrm{Mn}(\mathrm{IV})$ and $\mathrm{Mn}(\mathrm{II}) / \mathrm{Mn}(\mathrm{IV})$ species, respectively ${ }^{21}$. Other peaks $\left(\mathrm{A}_{3}, \mathrm{C}_{1}\right.$, and $\left.\mathrm{C}_{2}\right)$ all increased, indicating that $\mathrm{MnO}_{2}$ film can successfully grow on GC surface by further potential scanning.

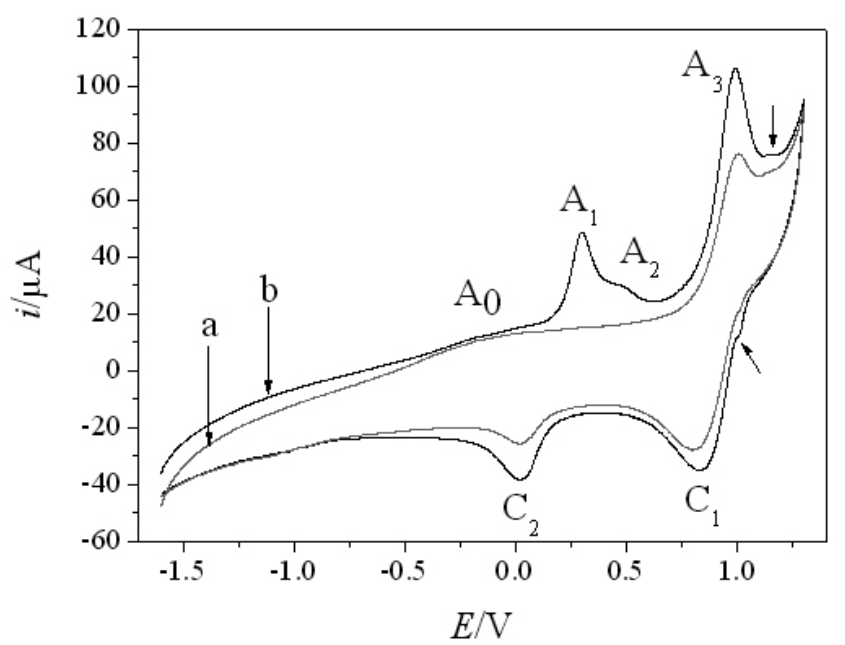

Fig. 1. Cyclic voltammograms of $\mathrm{GC}$ electrode in $0.6 \mathrm{~mol} \mathrm{~L}^{-1} \mathrm{KCl}$ solution containing $1.8 \mu \mathrm{mol} \mathrm{L}^{-1} \mathrm{Mn}^{2+}$.

$\mathrm{a}$ and $\mathrm{b}$ represent the first and second cyclic voltammogram, respectively. Scan rate: $0.02 \mathrm{~V} \mathrm{~s}^{-1}$; potential range: $-1.6 \sim 1.3 \mathrm{~V}$.

\section{Formation of manganese dioxide film on GC}

Fig. 2 shows the repetitive cyclic voltammograms of the deposition process of manganese dioxide on the surface of GC electrode in $0.1 \mathrm{~mol}$ $\mathrm{L}^{-1} \mathrm{NaOH}$ solution. There were two broad anodic peaks $\left(\mathrm{A}_{1}, \mathrm{~A}_{2}\right)$ in the first cyclic voltammogram, which was attributed to the oxidation of $\mathrm{Mn}$ to $\mathrm{Mn}$ (II) and Mn (II) to Mn (IV) ${ }^{6}$. The anodic peak currents(especially peak A, ) evidently declined during the first three voltammograms, which was attributed to manganese being basically oxidated to $\mathrm{Mn}$ (II) and manganese dioxide formed at the first scan blocked ion transfer. With the increase of scan number, they slowly rised, indicating the formation of manganese dioxide film. The anodic peak $\left(\mathrm{A}_{2}\right)$ at $0.35 \mathrm{~V}$ moved to $0.07 \mathrm{~V}\left(\mathrm{~A}_{3}\right)$ and the cathodic peak $\left(\mathrm{C}_{1}\right)$ moved from $-0.36 \mathrm{~V}$ to $-0.2 \mathrm{~V}$ with increasing cyclic number, suggesting the reversibility of manganese dioxide modified electrode.

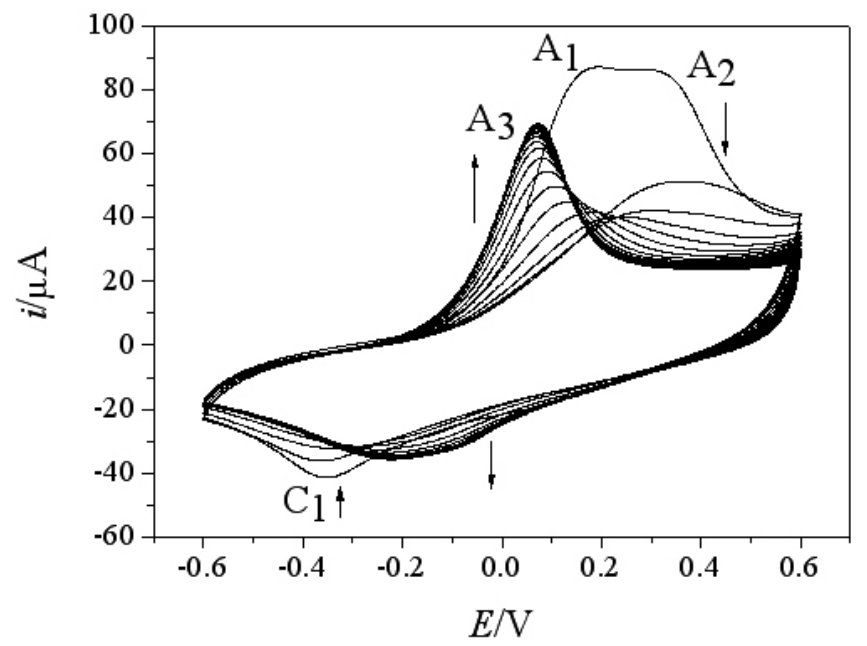

Fig. 2. Cyclic voltammograms of $\mathrm{Mn} / \mathrm{GC}$ in $0.1 \mathrm{~mol} \mathrm{~L}^{-1} \mathrm{NaOH}$ solution at scan rate of $0.05 \mathrm{~V} \mathrm{~s}^{-1}$.

After 20 cycles, the separation of anodic and cathodic peak potential $\left(\Delta E_{\mathrm{p}}\right)$ basically unchanged, showing that manganese dioxide film became uniform and dense and visible oxide layer was noticed by eye in this condition. No further peak current growth was observed, so 20 cycles was adopted in all cases. Whereafter, the electrode was rinsed thoroughly with distilled water and transferred into other solutions to study its electrochemical characteristics.

Film formation could be attributed to the formation of $\mathrm{Mn}(\mathrm{OH})_{4}^{-}$and $\mathrm{Mn}(\mathrm{OH})_{4}^{2-}$ on the condition of high concentration of sodium hydroxide ${ }^{27}$. $\mathrm{Mn}(\mathrm{OH})_{4}^{-}$and $\mathrm{Mn}(\mathrm{OH})_{4}{ }^{2-}$ were not stable and decomposited to $\mathrm{MnO}_{2}$. From the potential-pH diagram of $\mathrm{Mn}^{28}$, the anodic deposition of $\mathrm{MnO}_{2}$ from $\mathrm{Mn}^{2+}$ should occur in the potential range of $0 \sim 0.4 \mathrm{~V}$ at $\mathrm{pH} 13$, which was in accordance with the results of this work.

Factors influencing electrocatalytic activity of $\mathrm{MnO}_{2} / \mathrm{GC}$ electrode

Fig. 3 (a)-(c) shows the optimal factors for the preparation of $\mathrm{MnO}_{2} / \mathrm{GC}$ electrode by examining its catalytic activity for $\mathrm{H}_{2} \mathrm{O}_{2}$ oxidation. From the potential-pH diagram of $\mathrm{Mn}^{24}$, the cathodic deposition of $\mathrm{Mn}$ from $\mathrm{Mn}^{2+}$ should occur in the potential range under $-1.2 \mathrm{~V}$. The deposition rate of manganese film become fast when the cathodic deposition potential is lower. The film of manganese will be thicker for the same deposition time and ultimately makes the catalytic activity of $\mathrm{MnO}_{2} / \mathrm{GC}$ electrode changed. 

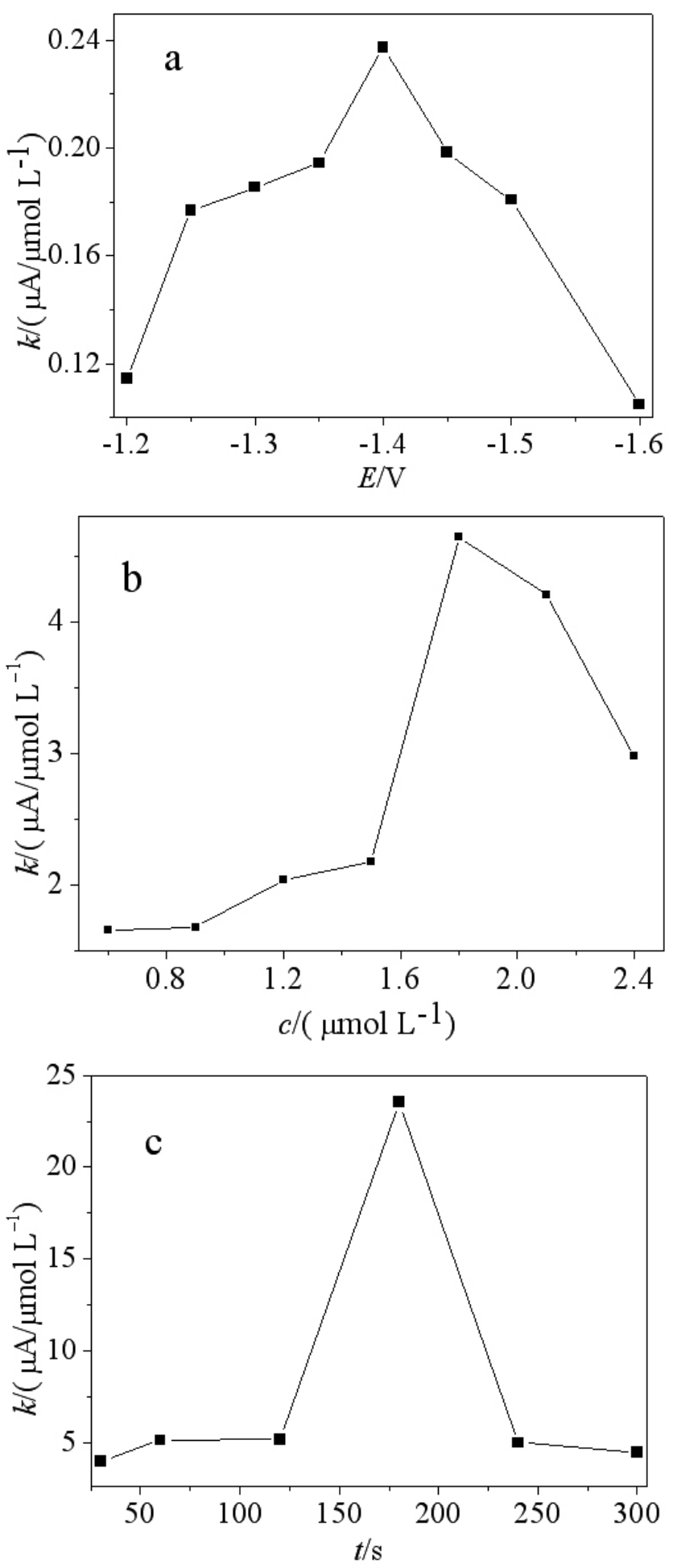

Fig. 3. Effect of the potential (a), $\mathrm{MnCl}_{2}$ concentration (b) and deposited time (c) of manganese film deposition on the electrocatalytic activity of $\mathrm{MnO}_{2} /$ $\mathrm{GC}$ electrode.

Fig. 3(a) illustrates the changing of electrocatalytic activity of $\mathrm{MnO}_{2} / \mathrm{GC}$ electrode for $\mathrm{H}_{2} \mathrm{O}_{2}$ oxidation in the deposition potential range $-1.2 \sim-1.6 \mathrm{~V}$, indicating the optimal deposition potential with high catalytic activity being $-1.4 \mathrm{~V}$. The more negative was the deposition potential, the higher was the catalytic activity, indicating that the number of active sites of manganese dioxide film played a major role. However, the catalytic ability decreased slowly when the deposition potential was less than $-1.5 \mathrm{~V}$, which may be attributed to the increasing of resistance of ion transfer for charge balance in the process of film oxidation and reduction ${ }^{29}$. Fig. 3 (b) shows the influence of $\mathrm{Mn}^{2+}$ concentration for manganese film deposition on the catalytic activity of $\mathrm{MnO}_{2} / \mathrm{GC}$ electrode. The optimal $\mathrm{Mn}^{2+}$ concentration was $1.8 \mu \mathrm{mol} \mathrm{L}^{-1}$, which was the result of interaction of active sites with film resistance by influencing the electrocatalytic activity of $\mathrm{MnO}_{2} / \mathrm{GC}$ electrode. Fig. 3(c) shows the effect of deposited time for manganese film growth on the electrocatalytic activity of $\mathrm{MnO}_{2} / \mathrm{GC}$ electrode. The deposited time determined the manganese film thickness and indirectly influenced the manganese dioxide film thickness on GC electrode. The manganese dioxide film could not completely coat the surface of the GC electrode for deposition times less than $30 \mathrm{~s}$ and lead to an insufficient number of active sites. With the deposition time increasing, the manganese dioxide film became thicker, which lead the number of active sites and the transfer resistance of electron and hydrogen peroxide in the film to synchronously increase. The suitable deposition time was $180 \mathrm{~s}$.

\section{Characterization of $\mathrm{MnO} / \mathrm{GC}$ electrode}

Fig. 4 shows a typical SEM image of electrodeposited manganese dioxide film adhered on GC electrode. It can be seen that a uniform film of manganese dioxide particles with average size of about $100 \mathrm{~nm}$ was distributed on the surface of electrode. Since the manganese dioxide film was formed by the direct oxidation of manganese on the electrode surface, the compact combination of manganese dioxide with electrode surface enhanced the transfer speed of electrons and further increased the catalytic activity of $\mathrm{MnO}_{2}$.

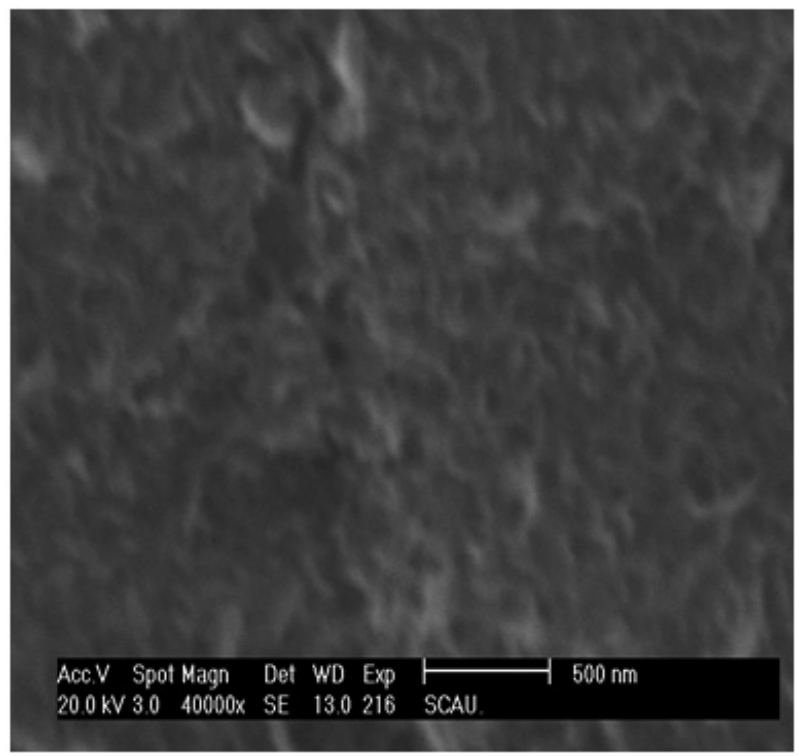

Fig. 4. SEM image of the electrodeposited manganese dioxide film on glassy carbon electrode surface.

Fig. 5 shows the recording cyclic voltammograms of $\mathrm{MnO}_{2} / \mathrm{GC}$ electrode in $0.1 \mathrm{~mol} \mathrm{~L}^{-1} \mathrm{NaOH}$ solution at various scan rates. As can be seen, increasing the scan rate the anodic and cathodic peak potentials shifted towards positive and negative directions, indicating charge transfer kinetics limitation. The results of the inset of Fig. 5 show that both the anodic and cathodic peak currents increase linearly with scan rates. The ratio of cathodic to anodic peak current is about unity as expected for surface bound redox sites. Thus, the overall redox process confined at the electrode surface can be considered to be relatively fast on the voltammetric time scale, which indicated that a surface confined redox process corresponded to rapid conversion of a surface film without diffusion or kinetically controlled reaction step. 


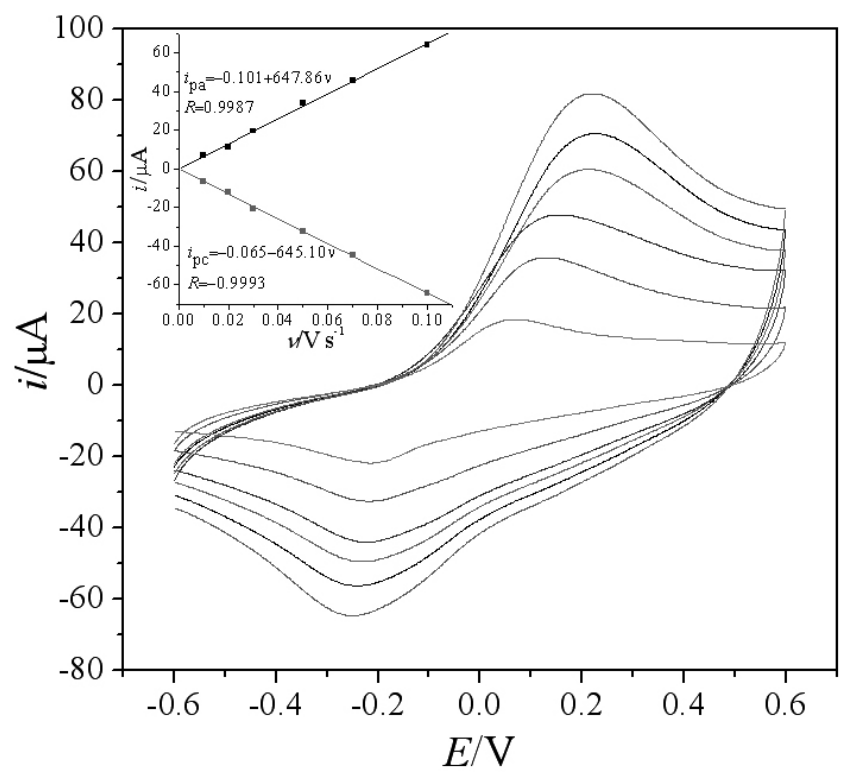

Fig. 5. Cyclic voltammetry response of $\mathrm{MnO}_{2} / \mathrm{GC}$ electrode in $0.1 \mathrm{~mol}$ $\mathrm{L}^{-1} \mathrm{NaOH}$ solution at different scan rates. from inner to outer: $0.01,0.02,0.03$, $0.05,0.07$ and $0.1 \mathrm{~V} \mathrm{~s}^{-1}$. Inset $\square$ plots of $\operatorname{anodic} \operatorname{peak}\left(i_{\mathrm{Pa}}\right)$ and cathodic peak $\left(i_{\mathrm{Pc}}\right)$ current $v s$. $\operatorname{scan} \operatorname{rate}(v)$.

At higher sweep rates, the peak potential was found to be dependent on scan rate, which was reflective of the relatively slow diffusion of hydroxide ions into the electrode surface. The surface concentration of electroactive species, $\Gamma$, can be calculated from the slope of the plot of $i_{\mathrm{pa}}$ versus scan rate $(v$ $<100 \mathrm{mV} \mathrm{s}^{-1}$ ) by the following equation ${ }^{30}$ :

$i=n^{2} F^{2} v A \Gamma_{\mathrm{c}} / 4 R T$

Where $v$ is the sweep rate, A is the surface area and the other symbols have their usual meaning. The calculated $\Gamma$ value can be approximately $4.86 \times 10^{-9}$ $\mathrm{mol} \mathrm{cm}-2$ for $\mathrm{MnO}_{2} / \mathrm{GC}$ electrode.

For investigating the repeatability of electrode modification process, five independent modified glassy carbon electrodes were prepared. Cyclic voltammograms of the prepared modified electrodes at scan rate $100 \mathrm{mV} \mathrm{s}^{-1}$ in $0.1 \mathrm{~mol} \mathrm{~L}^{-1} \mathrm{NaOH}$ solution were recorded (not shown). Almost same results were found for all electrodes. By measuring the anodic peak current at $0.22 \mathrm{~V}$ for five independently modified electrodes, the RSD value of about $5 \%$ was obtained, indicating good repeatability of the modification process.

Electrocatalytic oxidation of $\mathrm{H}_{2} \mathrm{O}_{2}$ on $\mathrm{MnO}_{2} / \mathrm{GC}$ electrode

Fig. 6 shows the cyclic voltammograms of $\mathrm{MnO}_{2} / \mathrm{GC}$ electrode in the absence and presence of $\mathrm{H}_{2} \mathrm{O}_{2}\left(0.11 \mathrm{mmol} \mathrm{L}^{-1}\right)$ at $\mathrm{pH}^{2} 7.38$ buffer solution. In order to verify the eletrocatalytic activity of the modified electrode for hydrogen peroxide oxidation, the electrochemical experiments in the presence of hydrogen peroxide were carried out. As shown for the bare glassy carbon electrode, no oxidation response of $\mathrm{H}_{2} \mathrm{O}_{2}$ can be seen in the potential range from 0 to $0.9 \mathrm{~V}$ (curve a and curve b). However, there was a pair of obvious redox peaks between 0.2 and $0.8 \mathrm{~V}$ (curve c) for $\mathrm{MnO}_{2} / \mathrm{GC}$ electrode in the absence of hydrogen peroxide ${ }^{31}$, which may be assigned to the redox pair $\mathrm{MnO}_{2} / \mathrm{Mn}(\mathrm{II})^{32-34}$.

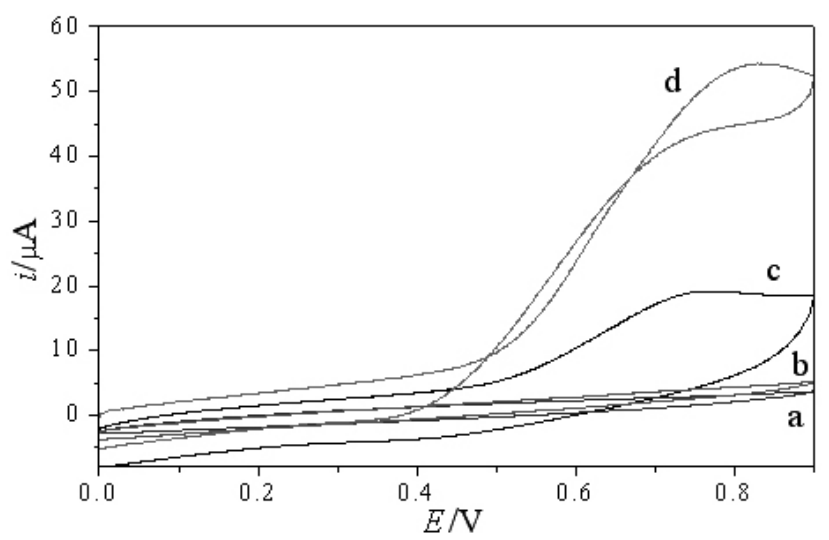

Fig. 6. Cyclic voltammograms of $\mathrm{MnO}_{2} / \mathrm{GC}$ (curve c,d) and bare $\mathrm{GC}$ (curve a, b) electrode in buffer solution $\mathrm{pH} 7.38$ at scan rate of $0.05 \mathrm{~V} \mathrm{~s}^{-1}$ in the absence (curve a, c) and presence (curve b, d) of $0.11 \mathrm{mmol} \mathrm{L}^{-1} \mathrm{H}_{2} \mathrm{O}_{2}$.

In the presence of $\mathrm{H}_{2} \mathrm{O}_{2}$, the oxidative peak current of $\mathrm{MnO}_{2}$ film greatly increased while the reductive peak disappeared (curve d). The overvoltage was decreased by about $0.35 \mathrm{~V}$ and the increased peak current of $\mathrm{H}_{2} \mathrm{O}_{2}$ oxidation confirmed that manganese dioxide nanoparticles had high catalytic ability for $\mathrm{H}_{2} \mathrm{O}_{2}$ oxidation ${ }^{16}$. The characteristic shape of the cyclic voltammogram in this potential region indicated that the signal was probably due to a parallel catalytic reaction. As soon as $\mathrm{MnO}_{2}$ was reduced to lower states by $\mathrm{H}_{2} \mathrm{O}_{2}$, they were electro-oxidized back to $\mathrm{MnO}_{2}$ at the electrode surface ${ }^{32}$ :

$\mathrm{MnO}+\mathrm{H}_{2} \mathrm{O}_{2} \rightarrow \mathrm{MnO}+\mathrm{H}_{2} \mathrm{O}+\mathrm{O}_{2}$

$\mathrm{MnO}+2 \mathrm{OH}^{-} \rightarrow \mathrm{MnO}_{2}+\mathrm{H}_{2} \mathrm{O}+2 \mathrm{e}^{-}$

Since the above reactions are fast, the parallel current is much higher than the oxidation current of $\mathrm{MnO}$ on the electrode surface without $\mathrm{H}_{2} \mathrm{O}_{2}$. Therefore, manganese dioxide nanoparticles are suitable as mediators to shuttle electrons between hydrogen peroxide and working electrode.

In order to optimize the electrocatalytic response of $\mathrm{MnO}_{2} / \mathrm{GC}$ electrode for hydrogen peroxide oxidation, the effect of electrolyte $\mathrm{pH}^{2}$ on $\mathrm{MnO}_{2} / \mathrm{GC}$ catalytic activity was investigated. The cyclic voltammograms of $\mathrm{MnO}_{2} / \mathrm{GC}$ electrode in $50 \mu \mathrm{mol} \mathrm{L} \mathrm{L}^{-1} \mathrm{H}_{2} \mathrm{O}_{2}$ at different $\mathrm{pH}$ values were recorded (Fig. 7). The $\mathrm{MnO}_{2} / \mathrm{GC}$ electrode showed electrocatalytic activity at different electrolyte $\left(\mathrm{pH}_{2} 4.92 \sim 9.18\right)$, but higher peak current was observed at $\mathrm{pH}$ 7.38 (Inset). The peak currents and potentials all changed with the changing of $\mathrm{pH}$ values. Peak potentials shifted positively with decreasing $\mathrm{pH}$ values. Since $\mathrm{MnO}_{2} / \mathrm{GC}$ electrode showed excellent response for trace amount of $\mathrm{H}_{2} \mathrm{O}_{2}$ at nearly physiological $\mathrm{pH}$ values of $7.0 \sim 8.0$, it can be used for detection of $\mathrm{H}_{2} \mathrm{O}_{2}$ generated by enzyme catalytic reactions. Fig. 8 shows the cyclic voltammograms of $\mathrm{MnO}_{2} / \mathrm{GC}$ electrode in electrolyte containing $41 \mathrm{nmol} \mathrm{L}^{-1}$ $\mathrm{H}_{2} \mathrm{O}_{2}$ at different scan rates. The peak current $\left(i_{\mathrm{pa}}\right)$ for the anodic oxidation of hydrogen peroxide is proportional to the square root of scan rate $\left(v^{1 / 2}\right)\left(i_{\mathrm{pa}}(\mu \mathrm{A})\right.$ $\left.=-4.1984+0.8090 v^{1 / 2}\left(\mathrm{mV} \mathrm{s}^{-1}\right)^{1 / 2}, R=0.9992\right)$, suggesting that the process is controlled by diffusion as expected for a catalytic system.

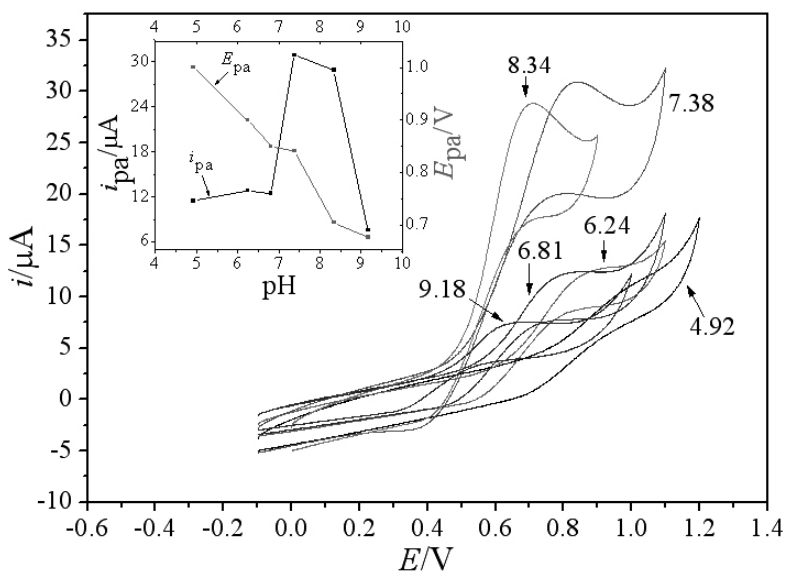

Fig. 7. Cyclic voltammograms of $\mathrm{MnO}_{2} / \mathrm{GC}$ electrode in different $\mathrm{pH}$ solutions in the presence of $50 \mu \mathrm{mol} \mathrm{L} \mathrm{L}^{-1} \mathrm{H}_{2} \mathrm{O}_{2}$. scan rate: $0.05 \mathrm{~V} \mathrm{~s}^{-1}$. Inset, plots of peak current and peak potential $v s$. $\mathrm{pH}$ values 


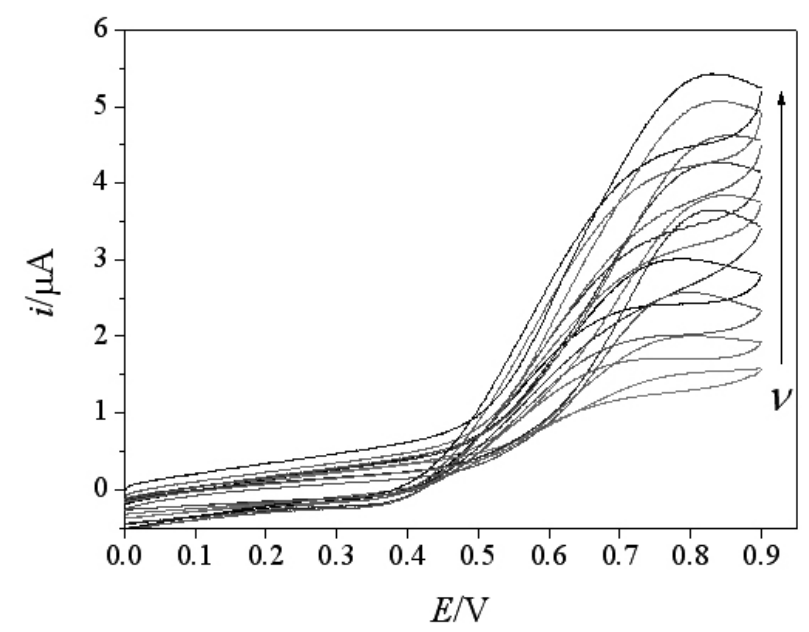

Fig. 8. Cyclic voltammetry response of $\mathrm{MnO}_{2} / \mathrm{GC}$ electrode in $\mathrm{pH} 7.38$ buffer solution containing $41 \mathrm{nmol} \mathrm{L}^{-1} \mathrm{H}_{2} \mathrm{O}_{2}$ at different scan rates of (lower to higher) $0.04,0.05,0.06,0.07,0.08,0.09,0.1,0.11,0.12$ and $0.13 \mathrm{~V} \mathrm{~s}^{-1}$.

\section{Amperometric determination of $\mathrm{H}_{2} \mathrm{O}_{2}$ on $\mathrm{MnO}_{2} / \mathrm{GC}$ electrode}

Since amperometry under stirred condition is much more sensitive than cyclic voltammetry, it is employed to estimate the detection low limit. Fig. 9 shows the steady-state catalytic current time response of $\mathrm{MnO}_{2} / \mathrm{GC}$ electrode with successive injection of $\mathrm{H}_{2} \mathrm{O}_{2}$ at the applied potential $0.6 \mathrm{~V}$ in buffer solution ( $\mathrm{pH}$ 7.38). As shown in the figure, a well response was observed during the successive addition of $0.41 \mu \mathrm{mol} \mathrm{L}{ }^{-1}$ (Fig. 9 A) and $4.1 \mathrm{nmol} \mathrm{L}^{-1}$ (Fig. 9 C) of $\mathrm{H}_{2} \mathrm{O}_{2}$, which demonstrated an effective catalytic property of $\mathrm{MnO}_{2}$ immobilized on GC.

There was a linear relationship between response current and hydrogen peroxide concentration in the range $0.1 \mathrm{mmol} \mathrm{L}^{-1}$ and $0.41 \mathrm{nmol} \mathrm{L}^{-1}$, while the plot of current $v s$. analyte concentration deviated from linearity for higher concentration of $\mathrm{H}_{2} \mathrm{O}_{2}$ (Fig. 9 B). The calibration curve for $\mathrm{H}_{2} \mathrm{O}_{2}$ measurement was presented in Fig. $9 \mathrm{D}$. The linear least squares calibration curve over the range of $4.1 \sim 100 \mathrm{nmol} \mathrm{L}^{-1}$ (25 points) was $\Delta i_{\mathrm{pa}}(\mu \mathrm{A})=0.0193 C_{\mathrm{H}_{2} \mathrm{O}_{2}}+0.125$ with the correlation coefficient being 0.9988 , demonstrating that the regression line was well fitted with the experimental data, and the detection lower limit was estimated to be $0.3 \mathrm{nmol} \mathrm{L}^{-1}(\mathrm{~S} / \mathrm{N}=3)$. Therefore, the regression equation can be used for the determination of $\mathrm{H}_{2} \mathrm{O}_{2}$ in real samples.

In addition, Fig. 9E shows the amperometric response of $41 \mu \mathrm{mol} \mathrm{L} \mathrm{L}^{-1}$ $\mathrm{H}_{2} \mathrm{O}_{2}$ during prolonged $27.5 \mathrm{~min}$ experiment. The response remained stable throughout the experiment, indicating that $\mathrm{MnO}_{2}$ nanoparticles showed high stability for amperometric measurements of $\mathrm{H}_{2} \mathrm{O}_{2} . \mathrm{MnO}_{2} / \mathrm{GC}$ electrode didn't lose activity with increasing time. $\mathrm{MnO}_{2} / \mathrm{GC}$ electrode was used each day for 10 measurements and each measurement took $1 \mathrm{~h}, 97 \%$ of the initial response of $\mathrm{MnO}_{2} / \mathrm{GC}$ electrode was retained after 30 days.

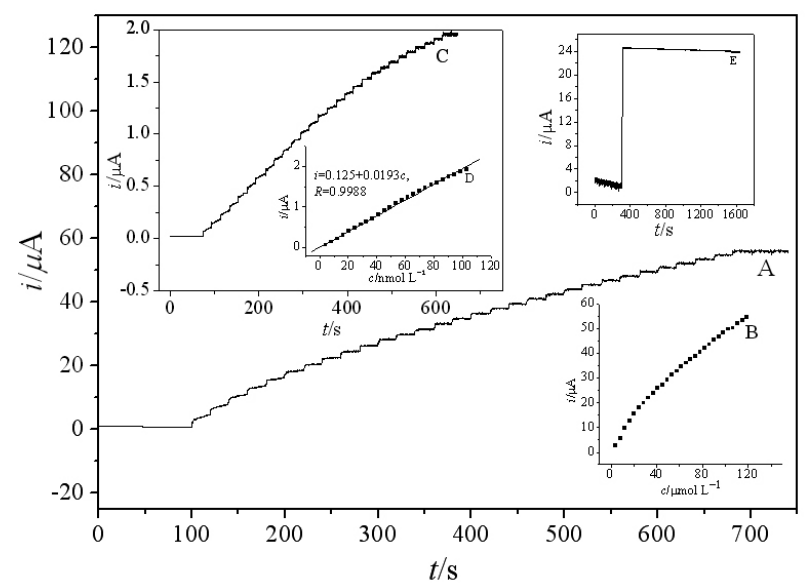

Fig. 9. Amperometric response of $\mathrm{MnO}_{2} / \mathrm{GC}$ electrode at potential $0.6 \mathrm{~V}$ in buffer solution ( $\mathrm{pH} 7.38$ ) for successive addition of $0.41 \mu \mathrm{mol} \mathrm{L}^{-1}(\mathrm{~A})$ and 4.1 nmol L-1 (C) of $\mathrm{H}_{2} \mathrm{O}_{2}$. (B), (D): plots of chronoamperometric current vs. $\mathrm{H}_{2} \mathrm{O}_{2}$ concentrations. (E): chronoamperogram for $4.1 \mu \mathrm{mol} \mathrm{L}^{-1} \mathrm{H}_{2} \mathrm{O}_{2}$ during a long period of time $(27.5 \mathrm{~min})$.

Four groups of substances that potentially coexist with $\mathrm{H}_{2} \mathrm{O}_{2}$ were investigated for interference on $\mathrm{H}_{2} \mathrm{O}_{2}$ (table 1). Most anions (Group 1) such as chlorate, sulfate, nitrate, ferricyanide didn't interfere when present in 100-fold mass. Amino acids (Group 2) slightly reduced the current of hydrogen peroxide if their concentration was 50 times the concentration of $\mathrm{H}_{2} \mathrm{O}_{2}$. Probably $\mathrm{H}_{2} \mathrm{O}_{2}$ in the sample solution may be consumed by redox processes. Substances that potentially existed in biological liquids (Group 3) interfered strongly. The amperometric response was markedly increased by ascorbate, dopamine and uric acid when the concentration of them was 50 times the concentration of $\mathrm{H}_{2} \mathrm{O}_{2}$, which may be attributed to the redox processes. The species existing in food and drug (Group 4) had little interference toward the signals of $\mathrm{H}_{2} \mathrm{O}_{2}$. Thus, the $\mathrm{H}_{2} \mathrm{O}_{2}$ sensor can be used for the determination of $\mathrm{H}_{2} \mathrm{O}_{2}$ in water, foods, drugs and cosmetics except the biological molecules in high concentration.

Table 1 Relative changes in current response of $41 \mu \mathrm{mol} \mathrm{L}^{-1} \mathrm{H}_{2} \mathrm{O}_{2}$ in the presence of interferents*

\begin{tabular}{|c|c|c|c|c|}
\hline \multirow{2}{*}{ groups } & \multirow{2}{*}{ interferents } & \multicolumn{3}{|c|}{ Relative Changes in Current(\%) } \\
\cline { 3 - 5 } & & $\begin{array}{c}0.41 \\
\mathrm{mmol} \mathrm{L}^{-1}\end{array}$ & $2.05 \mathrm{mmol} \mathrm{L}^{-1}$ & $4.1 \mathrm{mmol} \mathrm{L}^{-1}$ \\
\hline 1 & $\mathrm{NaCl}$ & 0 & 0 & 0 \\
\hline & $\mathrm{Na}_{2} \mathrm{SO}_{4}$ & 0 & 0 & 0 \\
\hline & $\mathrm{NaNO}_{3}$ & 0 & 0 & 0 \\
\hline & $\mathrm{K}_{3} \mathrm{Fe}(\mathrm{CN})_{6}$ & 0 & $<2$ & $<2$ \\
\hline 2 & $\mathrm{Gly}$ & 0 & -14 & -30 \\
\hline & L-Try & 0 & -19 & -32 \\
\hline & Glu & 0 & -11 & -24 \\
\hline 3 & Ascorbate & 5 & 50 & 273 \\
\hline & Dopamine & 27 & 136 & 450 \\
\hline & Uric acid & 8 & 12 & 89 \\
\hline 4 & Caffeine & 0 & 0 & 0 \\
\hline & Barbitone & 0 & 0 & 0 \\
\hline & Oxammonium & 0 & $<2$ & 11 \\
\hline
\end{tabular}

* Determined by amperometry; operating potential, $0.6 \mathrm{~V}$; phosphate buffer $\left(1 / 15 \mathrm{~mol} \mathrm{~L}^{-1}, \mathrm{pH} 7.38\right)$ containing $0.1 \mathrm{~mol} \mathrm{~L}^{-1} \mathrm{KCl}$

$\mathrm{H}_{2} \mathrm{O}_{2}$ in real water taken from Poyang Lake(rain water) in our campus was measured. The results $(45.8 \mu \mathrm{g} / \mathrm{g})$ agreed well with the $\mathrm{KMnO}_{4}$ titration method $(47.2 \mu \mathrm{g} / \mathrm{g})$. The fresh water sample was dissolved in deionized water to certain volume before analysis. Amperometric determinations were carried out by directly adding the dissolved water solution after adding $0.2,0.4,0.6 \mathrm{mmol} \mathrm{L}^{-1}$ $\mathrm{H}_{2} \mathrm{O}_{2}$ as the internal standards. The recovery of experiments was from $95.93 \%$ to $104.47 \%$ for 3 parallel measurements, which further proved that the sensor could be used to measure $\mathrm{H}_{2} \mathrm{O}_{2}$ in real samples.

\section{CONCLUSION}

A novel film plating/potential cycling method has been developed for electrodeposition of manganese dioxide nanoparticles on the surface of glassy carbon electrode. It provides an effective way for the preparation of a new class of sensitive, stable and reproducible hydrogen peroxide electrochemical sensor. The advantages of modification procedure are less expensive and more convenient than those used by others. The fast response and high sensitivity of this $\mathrm{H}_{2} \mathrm{O}_{2}$ sensor are attributed to the compaction between manganese dioxide and glassy carbon electrode for electron transmission and the high specific surface area of $\mathrm{MnO}_{2}$ for a uniform film. In addition, the electrooxidation of nanomolar hydrogen peroxide solution at reduced overpotential was performed using $\mathrm{MnO}_{2} / \mathrm{GC}$ electrode. Its applicability to practical samples was verified by measuring $\mathrm{H}_{2} \mathrm{O}_{2}$ in real water of Poyang lake, which held promise for the quantitative detection of $\mathrm{H}_{2} \mathrm{O}_{2}$, specially lower detection limit and its applicability in neutral solution, suggesting that the film plating/cyclic voltammetry method can probably act as a novel and useful method for the preparation of electrochemical sensors. 


\section{ACKNOWLEDGMENTS}

Project is supported by the Scientific Research Starting Foundation for Drs., Natural Science Foundation of Guangdong Province, China (Grant No. 5300842) and the President Science Foundation of South China Agricultural University (Grant No. 2005K119)

\section{REFERENCES}

[1] Y.-Q. Liu, Y. Yan, H.-X. Shen, Chin. J. Chem. 23, 1165, (2005).

[2] S. V. Aurobind, K. P. Amirthalingam, H. Gomathi, Adv. Colloid Interface Sci. 121, 1, (2006).

[3] D. Zhang, D. Chi, T. Okajima, T. Ohsaka, Electrochim. Acta 52, 5400, (2007).

[4] E. Elangovan, K. Ramesh, K. Ramamurthi, Solid State Commun. 130, $523,(2004)$.

[5] R. J. Collina, C. N. Sukenik, Langmuir 11, 2322, (1995)

[6] Z. Taba, J. Wang, Electroanalysis 3, 215, (1991).

[7] J. A. Cox, P. J. Kulesza, Anal. Chem. 56, 1021, (1984).

[8] S. V. Prabhu, R. P. Baldwin, Anal. Chem. 61, 2258, (1989).

[9] J. Wang, Z. Taha, Anal. Chem. 62, 1413, (1990).

[10] G. A. Edwards, A. J. Bergren $\square$ M. D. Porter in: C. G. Zoski(Ed.), Handbook of Electrochemistry, Elsevier Science, Amsterdam, 2007, 295-327.

[11] Y. J. Fenga, X. Y. Li, Water Res. 37, 2399, (2003).

[12] J. M. Hu, J. Q. Zhang, C. N. Cao, Int. J. Hydrogen Energy 29, 791, (2004).

[13] J. R. C. D. Rocha, T. L. Ferreira, R. M. Torresi, M. Bertotti, Talanta 69, $148,(2006)$

[14] V. Sáez, J. González-García, J. Iniesta, A. Frías-Ferrer, A. Aldaz. Electrochem. Commun. 6, 757, (2004).

[15] P. Shakkthivel, S. M. Chen, Biosens. Bioelectron. 22, 1680, (2007).

[16] A. Salimi, R. Hallaj, S. Soltanian, H. Mamkhezri, Anal. Chim. Acta 594, 24, (2007).
[17] E. Turkusic, J. Kalcher, E. Kahrovic, N. W. Beyene, H. Moderegger, E. Sofic, S. Begic, K. Kalcher, Talanta 65, 559, (2005).

[18] M. O. Danilov, A. V. Melezhyk, J. Power Sources 163, 376, (2006).

[19] M. Ghaemi, L. Khosravi-Fard, J. Neshati, J. Power Sources 141, 340, (2005).

[20] Z. Taba, J. Wang, Electroanalysis 3, 215, (1991).

[21] Y. H. Bai, Y. Du, J. J. Xu, H. Y. Chen, Electrochem. Commun. 9, 2611, (2007).

[22] M. O. Danilov, A. V. Melezhyk, J. Power Sources 163, 376, (2006).

[23] E. C. Rios, A. V. Rosario, R. M. Q. Mello, L. Micaroni, J. Power Sources 163, 1137, (2007)

[24] X. Xia, Chin. Battery Industry 10, 118, (2005).

[25] J. P. Petitpierre, C. Comninellis, E. Plattner, Electrochim. Acta 35, 281, (1990).

[26] A. Manivel, N. Ilayaraja, D. Velayutham, M. Noel, Electrochim. Acta 52, 7841, (2007).

[27] A. J. Bard, Encyclopedia of Electrochemistry of the Elements. Vol. 1, Marcel Dekker, New York, 1973.

[28] M. Pourbaix, Atlas of Electrochemical Equilibria in Aqueous Solutions, 2nd ed., National Association of Corrosion Engineers, Houston, 1974, p. 378.

[29] C. Barbero, G. A. Planes, M. C. Miras, Electrochem. Commun. 3, 113, (2001).

[30] A. J. Bard, L. R. Faulkner, Electrochemical Methods: Fundamentals and Applications, 2nd ed. John Wiley and Sons, New York, 2001.

[31] S. Yao, S. Yuan, J. Xu, Y. Wang, J. Luo, S. Hu, Appl. Clay Sci. 3, 35, (2006).

[32] T. Emir, K. Kalcher, K. Schachl, A. Komersova, M. Bartos, H Moderegger, I. Svancara, K. Vytras, Anal. Lett. 34, 2633, (2001).

[33] L. Yin, J. Chou, W. Chung, T. Sun, K. Hsiung, S. Hsiung, Sens. Actuators $B$ 76, 187, (2001).

[34] S. B. Hocevar, B. Ogorevc, K. Schachl, K. Kalcher, Electroanalysis 16, 1711, (2004). 